\title{
Importance of brassinosteroids in activating the antioxidant system and growth in Jatropha curcas L. plants under water deficit
}

\author{
Diego Braga de Oliveira ${ }^{1}$, Camila Lariane Amaro', Liana Verônica Amaro', Larissa Pacheco \\ Borges ${ }^{1}$, Victor Alves Amorim ${ }^{1}$, Fábio Santos Matos ${ }^{2}$ \\ ${ }^{1}$ Post-Graduate in Plant Production of UEG, Ipameri University Unit, Brazil \\ ${ }^{2}$ Graduate Program in Plant Production of UEG, Ipameri University Unit, GO 330, Km 241, ring road, university sector, \\ 75780-000-Ipameri, GO, Brazil
}

*Corresponding author: fabio.agronomia@hotmail.com

\begin{abstract}
Climatic changes and drought reduced plant growth and development. Brassinosteroids act in maintaining turgor and plant growth, increasing tolerance to water stress. The objective of the present study was to identify the effect of brassinosteroids in reducing stresses caused by water deficit in Jatropha curcas L. plants. The study was carried out in a greenhouse at the State University of Goiás, in a completely randomized block design in a factorial $2 \times 5$ arrangement (plants submitted to five brassinosteroids concentrations $(0,2$, $4,8,16 \mathrm{mg} \mathrm{L}^{-1}$ ) and two levels of daily water supply (50\% and $100 \%$ evapotranspiration) six replications and the plot consisted of one useful plant. A $10 \mathrm{~mL}$ volume of the hormone was applied 30 days after emergence and $20 \mathrm{~mL}$ at 60 days after emergence, totaling 30 $\mathrm{ml}$. The water deficit was imposed at 70 days after emergence and the evaluations were made at $100 \mathrm{~d}$ after emergence. Under water deficit, production increased of reactive substances that damage membranes and proteins, but brassinosteroids played an important role in mitigating the deleterious effects of water deficit on J. curcas plants by acting as an elicitor in activating photoprotection mechanisms that increased vegetative growth and maintained membrane integrity. The antioxidant and growth machinery activation reached maximum points at the $8 \mathrm{mg} \mathrm{L}^{-1}$ brassinosteroids concentration and even higher concentrations.
\end{abstract}

Keywords: biofuel; drought; Jatropha curcas; photoprotection; plant hormone.

Abbreviations: Br_Brassinosteroids; CAT_Catalase; DAE_Days after emergency; EDTA_2,2',2",2"'-(Ethane-1,2-diyldinitrilo) tetraacetic acid; ETc _Crop evapotranspiration; ETo _Reference evapotranspiration; $\mathrm{H}_{2} \mathrm{O}_{2}$ _Hydrogen peroxide; INMET_National Institute of Meteorology; Kc_Crop coefficient; LEA_Late embryogenesis abundant; POD_Guaiacol peroxidase; SOD_ Superoxide dismutase; TBARS_Thiobarbituric acid-reactive species; WS_Water supply.

\section{Introduction}

The growing world concern with the environment due to high greenhouse gas emission has intensified the search for cleaner and more sustainable energetic alternatives, such as biofuels derived from vegetable oil that represent an important replacement source for fossil fuels. Crops with potential for biofuel production include Jatropha curcas L. due to the oil content extracted from seeds $(22 \%-44 \%)$ that has similar energetic potential to diesel (Durães et al., 2011).

The $J$. curcas species is a perennial bush plant native to Central America, belonging to the family Euphorbiaceae (Chaves et al., 2014). In addition to raw material for biofuel production, it is used to produce biopesticides, cosmetics and medications from the latex that has antimicrobial, anti-cancer and antiinflammatory activities (Matos et al., 2018). The plant is considered xerophyte and robust because it develops well under adverse conditions of salinity, poorly drained soils, nutritional deficiency and water deficit (Matos et al., 2014; Dos Anjos et al., 2017). Despite presenting drought tolerance, the
Jatropha curcas plant under water restriction presents growth paralysis, reductions in the number of fertilized flowers and grain yield (Matos et al., 2014). The development of management techniques that ensure minimum growth, even if low in the period of water deficiency, may increase the productivity and profitability of the species.

Water deficiency is the most important constraint on agricultural productivity. Approximately $35 \%$ of the terrestrial surface does not receive sufficient rainfall for adequate water supply to most cultivated species (Diaz-lópez et al., 2012). Global warming has accentuated extreme events such as droughts in countless regions of the planet. As water resources become scarce, the development of management technologies becomes a priority to mitigate the damage caused by stress. Efficient water use permits a flow of nutrients from the roots to the leaves, while water deficit interferes negatively in the cell metabolism, reducing stomata control, leaf transpiration and $\mathrm{CO}_{2}$ supply for photosynthesis (Osakabe et al., 2014). 
Under these conditions, growth regulators, specifically the brassinosteroids, have been widely used to minimize the damage caused by stress in agricultural species (Divi et al., 2016).

The brassinosteroids $(\mathrm{Br})$ are steroid hormones that act in cell expansion and division, with biological effects at low concentrations (Unterholzner et al., 2015). Their use is associated to increase in biomass, adaptation to environmental factors, stimulation to stem and root lengthening, induction of ethylene synthesis, seed germination and antioxidant enzyme activation (Hilgenberg et al., 2014). The $\mathrm{Br}$ stimulate certain enzymes that play an important role in metabolism and can both promote and inhibit root growth according to the concentration (Hilgenberg et al., 2014). The increase in scenarios of climatic changes and droughts has led to the development of management techniques that enable commercial exploitation of species under water restriction. The use of $\mathrm{Br}$ to attenuate water deficit may contribute to maintaining turgor and plant growth. Thus, the objective of the present study was to identify the effect of brassinosteroids in attenuating stress caused by water deficit in J. curcas plants.

\section{Results and Discussion}

The summary of the ANOVA for plant height, stem diameter, leaf area, transpiration and root length are shown in Table 1. Water deficit and the brassinosteroids interfered decisively in J. curcas plant growth, but the interaction between brassinosteroid concentrations and water deficit was significant only for stem diameter, transpiration and root length. Plant height, stem diameter, leaf area and transpiration were $14 \%, 15 \%, 40 \%$ and $47 \%$ higher in plants irrigated with $100 \%$ water supply compared to the plants under water deficit, respectively. Turgor pressure is an indispensable condition for plant growth and the start of the first leaf. Under water deficit J. curcas plants showed limited vegetative development. Root length was $12 \%$ longer in the plants under water deficit compared to those irrigated with $100 \%$ water supply. The canopy is the first to deal with water deficit and as a consequence separates assimilates for the root system to continue growing towards moisture at greater depths. The results corroborate those found by Fini et al. (2013), who identified alteration in the root/canopy ratio in plants under water deficit.

Biomass, total chlorophyll, maximum quantum yield of photosystem II and starch content showed 61\%, 33\%, 4\% and $5 \%$ reductions in plants under water deficit compared to those irrigated with $100 \%$ water supply, respectively (Table 2 ). Water limitation reduced transpiration by reducing stomata opening, limiting the $\mathrm{CO}_{2}$ inflow and consequently photosynthesis and biomass accumulation. Leaf concentrations of carotenoids, electrolyte leakage and thiobarbituric acid-reactive substances were $38 \%, 39 \%$ and $16 \%$ higher in plants under water deficit compared to $100 \%$ water supply, respectively. Reduced chlorophyll and increased carotenoids may be associated to excess excitation energy, because when the stomata limit $\mathrm{CO}_{2}$ diffusion, lipid peroxidation and cell damage, chemical energy may accumulate and in these circumstances the $J$. curcas plant reduces luminous energy absorption with less chlorophyll, eliminates reactive species and increases carotenoids. Results corroborated those found by Matos et al. (2014) by identifying increases in leaf carotenoid concentration in Jatropha curcas plants under water deficit.

The activities of catalase, superoxide dismutase, guaiacol peroxidase enzymes, protein content and reducing sugars were $47 \%, 59 \%, 52 \%, 23 \%$ and $92 \%$ higher in plants under water deficit compared to those irrigated with $100 \%$ water supply, respectively (Table 3 ). The total soluble sugars and non-reducing sugars were $14 \%$ and $40 \%$ higher in irrigated plants compared to those under water deficit, respectively. The small difference in quantum yield indicated that water stress did not damage electron transport which was probably due to the efficient antioxidant mechanism present in J. curcas leaves. Electrolyte leakage, the presence of thiobarbituric acidreactive substances and antioxidant enzyme activity are evidence of the presence of toxic compounds and an efficient removal system. The higher sugar concentration in plants under water deficit may be related to a higher concentration in the root system that requires glucose for respiration and metabolic energy supply. Antioxidant enzyme activities and increased leaf carotenoid concentration are important tolerance mechanisms to abiotic stresses (Khamsuk et al., 2018).

The graphs with regression curves and maximum points for leaf area, total biomass, transpiration, carotenoids, total chlorophyll and electrolyte leakage are shown in Fig 1. Brassinosteroids interfered significantly in J. curcas vegetative growth. The increases in leaf area, photosynthetic pigments and transpiration via stomata opening in plants treated with $\mathrm{Br}$ were indicative of higher photosynthetic activity and consequently increased biomass accumulation. The brassinosteroids stimulate cell expansion and protect the photosynthesis apparatus against damage from environmental stressors. According to Bartwal et al. (2013), brassinosteroids are highly promising natural substances offering wide protection for plants against abiotic stresses. This hormone can override stomata control of the $\mathrm{CO}_{2}$ inflow and prevent photosynthetic pigment loss by activating or inducing the synthesis of enzymes involved in chlorophyll biosynthesis (Siddiqui et al., 2018).

The increase in carotenoid concentration and reduction in electrolyte leakage indicate the importance of the brassinosteroids in plant photoprotection. The significance was shown in the control and stressed plants, but brassinosteroid action in photoprotection was more effective in plants under water deficit. According to Khamsuk et al., (2018) brassinosteroids play an important role in photoprotection by maintaining membrane integrity and diminishing the impact of drought on physiologic responses.

Fig 2 shows regression curves and points of maximum quantum efficiency of photosystem II, activities of guaiacol peroxidase, catalase, superoxide dismutase, thiobarbituric acid-reactive species (TBARS), concentrations of leaf reducing sugars, proteins and total soluble sugars. Brassinosteroids play an important role in activating the anti-oxidation metabolism in $J$. curcas plants by promoting greater activity of the first enzymatic defense line, superoxide dismutase and next, removal of reactive compounds (TBARS) under the action of the other enzymes so that photosystem $\left(\mathrm{F}_{\mathrm{v}} / \mathrm{F}_{\mathrm{m}}\right)$ is protected and membrane integrity maintained. According to Siddiqui et al., (2018) brassinosteroids play an important role in obtaining 
Table 1. Summary of the ANOVA and means test for plant height (PH), stem diameter (SD), leaf area (LA), transpiration (E) and root length (RL) in Jatropha curcas plant submitted to water deficit (WD) and different brassinosteroids concentrations (Br).

\begin{tabular}{|c|c|c|c|c|c|c|}
\hline \multicolumn{7}{|c|}{ Mean squares } \\
\hline SV & $\mathrm{DF}$ & $\mathrm{PH}$ & SD & LA & $E$ & $\mathrm{RL}$ \\
\hline & & $\mathrm{cm}$ & $\mathrm{mm}$ & $\mathrm{m}^{2}$ & $\mathrm{~g} \mathrm{H}_{2} \mathrm{O} \mathrm{d}^{-1}$ & $\mathrm{~cm}$ \\
\hline $\mathrm{Br}$ & 4 & $76.16^{* *}$ & $10.9^{* *}$ & $65.8^{* *}$ & $4.9 \mathrm{E}+4 * *$ & $378.0 * *$ \\
\hline WD & 1 & $1555.1^{* *}$ & $446.6^{* *}$ & $761.2^{* *}$ & $2.0 \mathrm{E}+5^{* *}$ & $371.2^{* *}$ \\
\hline$B r \times W D$ & 4 & $29.7^{\text {ns }}$ & $27.6^{* *}$ & $4.4^{\text {ns }}$ & 4.7E+3** & $27.7^{* *}$ \\
\hline Residue & 50 & 25.60 & 1.9 & 3.5 & 1457.0 & 6.0 \\
\hline$C V, \%$ & & 7.4 & 4.3 & 13.4 & 20.6 & 6.2 \\
\hline \multicolumn{3}{|c|}{ Water supply } & \multicolumn{4}{|l|}{ Means } \\
\hline $100 \%$ & & $73.77 a$ & $35.82 a$ & $17.59 a$ & $242.3 a$ & $37.31 \mathrm{~b}$ \\
\hline $50 \%$ & & $63.59 \mathrm{~b}$ & $30.36 \mathrm{~b}$ & $10.47 \mathrm{~b}$ & $128.0 \mathrm{~b}$ & $42.28 \mathrm{a}$ \\
\hline
\end{tabular}

*Significant at $5 \%$ probability; ${ }^{* *}$ significant at $1 \%$ probability; ns: nonsignificant by the $\mathrm{F}$ test. Means followed by the same uppercase letter in the column do not differ at $5 \%$ probability by the NewmanKeuls test. Variation Source (SV), degrees of freedom (DF).
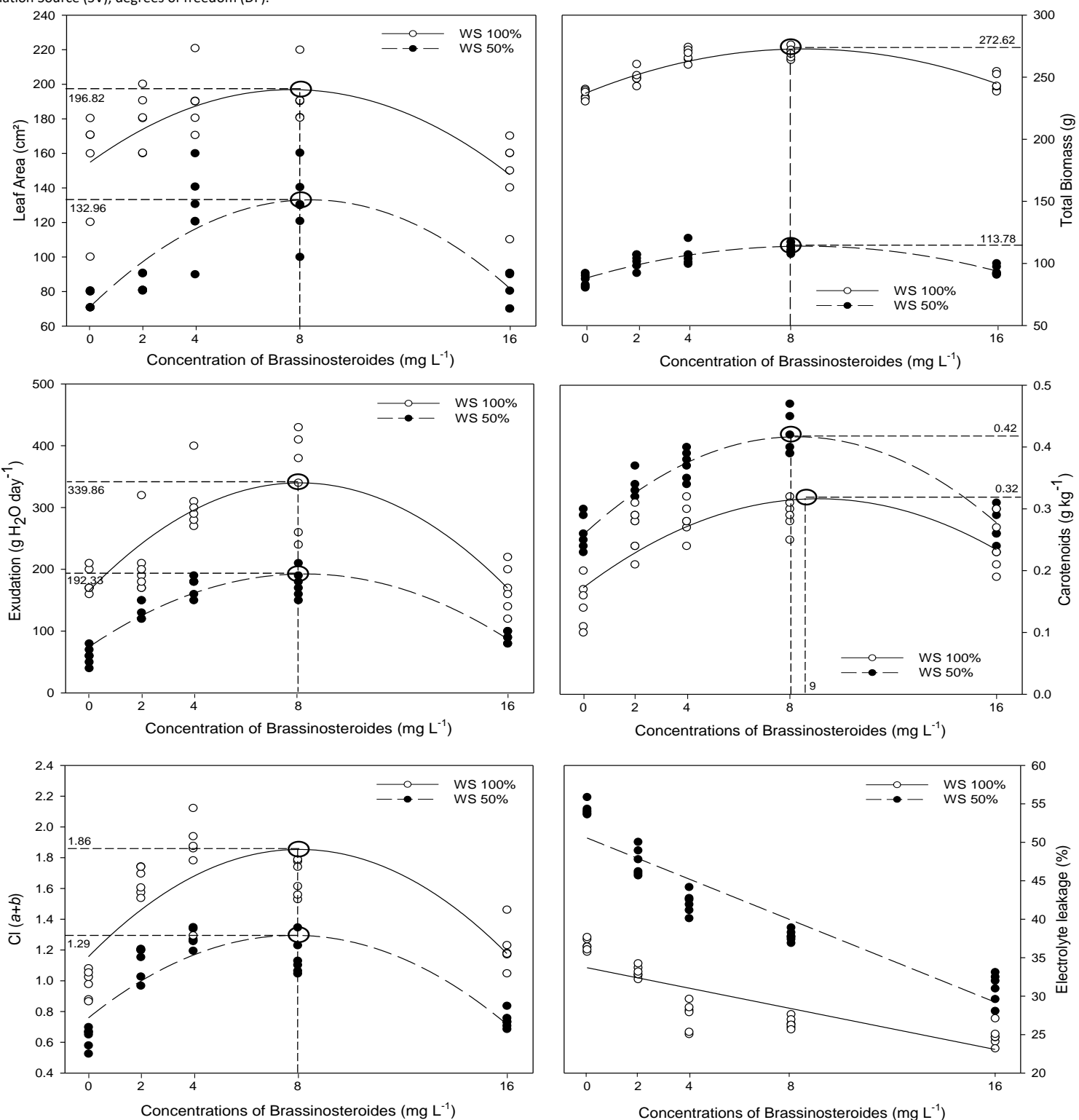

Fig 1. Regression equations for leaf area (WS 50\%: $y=-0.881 x^{2}+14.7 x+71.1 . R^{2}=0.81 * *$; WS $100 \%: y=-0.711 x^{2}+10.9 x+154.8 . R^{2}=$ $0.71^{* *}$ ), total biomass (WS 50\%: $y=-0.357 x^{2}+6.08 x+87.9 . R^{2}=0.91 * *$; WS $100 \%: y=-0.496 x^{2}+8.42 x+236.9 . R^{2}=0.92 * *$, transpiration (WS 50\%: $y=-1.74 x^{2}+28.6 x+74.4 . R^{2}=0.92 * *$; WS 100\%: $y=-2.69 x^{2}+43.3 x+165.3 . R^{2}=0.87 * *$ ), carotenoids (WS $50 \%$ : $y=-0.0023 x^{2}+0.038 x+0.258 . R^{2}=0.92 * * ;$ WS $\left.100 \%: y=-0.0017 x^{2}+0.031 x+0.172 . R^{2}=0.83^{* *}\right)$, total chlorophylls $(a+b)$ (WS 50\%: $y=$ $-0.0087 x^{2}+0.136 x+0.758 . R^{2}=0.90^{* *}$; WS $100 \%: y=-0.0107 x^{2}+0.173 x+1.15 . R^{2}=0.87^{* *}$ ) and electrolyte leakage (WS $50 \%: y=-$ 1.33x + 50.5. $R^{2}=0.95^{* *}$; WS $100 \%: y=-0.664 x+33.6 . R^{2}=0.90^{* *}$ ) of Jatropha curcas plants under different brassinosteroid concentrations and water supply (WS) levels. Regression equations significant at ${ }^{*} 5 \%$ and $* * 1 \%$ probability. 
Table 2. Summary of the ANOVA and means test for total biomass (Biom), total chloropylls (Chl total), carotenoids (Car), maximum quantum efficiency of photosystem II $\left(\mathrm{F}_{\mathrm{v}} / \mathrm{F}_{\mathrm{m}}\right)$, electrolyte leakage (EL), starch content $(\mathrm{SC})$ and thiobarbituric acid-reactive substances (TBARS) in Jatropha curcas plants submitted to water deficit (WD) and different brassinosteroids (Br) concentrations.

\begin{tabular}{|c|c|c|c|c|c|c|c|c|}
\hline \multirow[b]{2}{*}{ SV } & \multicolumn{7}{|c|}{ Mean squares } & \multirow[b]{2}{*}{ TBARS } \\
\hline & $\mathrm{DF}$ & Biom & $\mathrm{Cl}$ total & Car & $\mathrm{F}_{\mathrm{v}} / \mathrm{F}_{\mathrm{m}}$ & EL & $\mathrm{SC}$ & \\
\hline & & $\mathrm{g} \mathrm{pl}^{-1}$ & $-\mathrm{g} \mathrm{kg}^{-1}-$ & & & $\%$ & & $\mathrm{nmol} \mathrm{g}^{-1}$ \\
\hline $\mathrm{Br}$ & 4 & $1827.1^{* *}$ & $11.0 * *$ & $65.8^{*}$ & $892.1^{* *}$ & $884.4^{* *}$ & $2.4^{* *}$ & $43.0^{* *}$ \\
\hline WD & 1 & $3.5 \mathrm{E}+5^{* *}$ & $446.6 *$ & $761.2^{*}$ & $6023.6^{*}$ & $2095.1^{* *}$ & $0.1^{* *}$ & $875.6^{*}$ \\
\hline $\mathrm{Br} \times W D$ & 4 & $29.7^{\mathrm{ns}}$ & $27.6 * *$ & $4.4^{\mathrm{ns}}$ & $64.4^{* *}$ & $689.3^{* *}$ & $0.02^{\mathrm{ns}}$ & $1.0^{* *}$ \\
\hline Residue & 50 & 25.6 & 2.0 & 3.5 & 8.7 & 10.2 & 0.01 & 0.1 \\
\hline$C V, \%$ & & 3.0 & 4.3 & 13.4 & 5.0 & 8.8 & 6.6 & 3.6 \\
\hline Water supply & & & Means & & & & & \\
\hline $100 \%$ & & $253.79 a$ & $1.47 a$ & $0.24 \mathrm{~b}$ & $0.81 a$ & $30.20 \mathrm{~b}$ & $1.85 a$ & $6.60 \mathrm{~b}$ \\
\hline $50 \%$ & & $100.18 b$ & $0.99 b$ & $0.33 a$ & $0.78 b$ & $42.02 \mathrm{a}$ & $1.76 \mathrm{~b}$ & $14.24 a$ \\
\hline
\end{tabular}

*Significant at $5 \%$ probability; ${ }^{* *}$ significant at $1 \%$ probability; ns: nonsignificant by the $\mathrm{F}$ test. Means followed by the same uppercase letter in the column do not differ at $5 \%$ probability by the Newman-Keuls test. Variation Source (SV), degrees of freedom (DF).
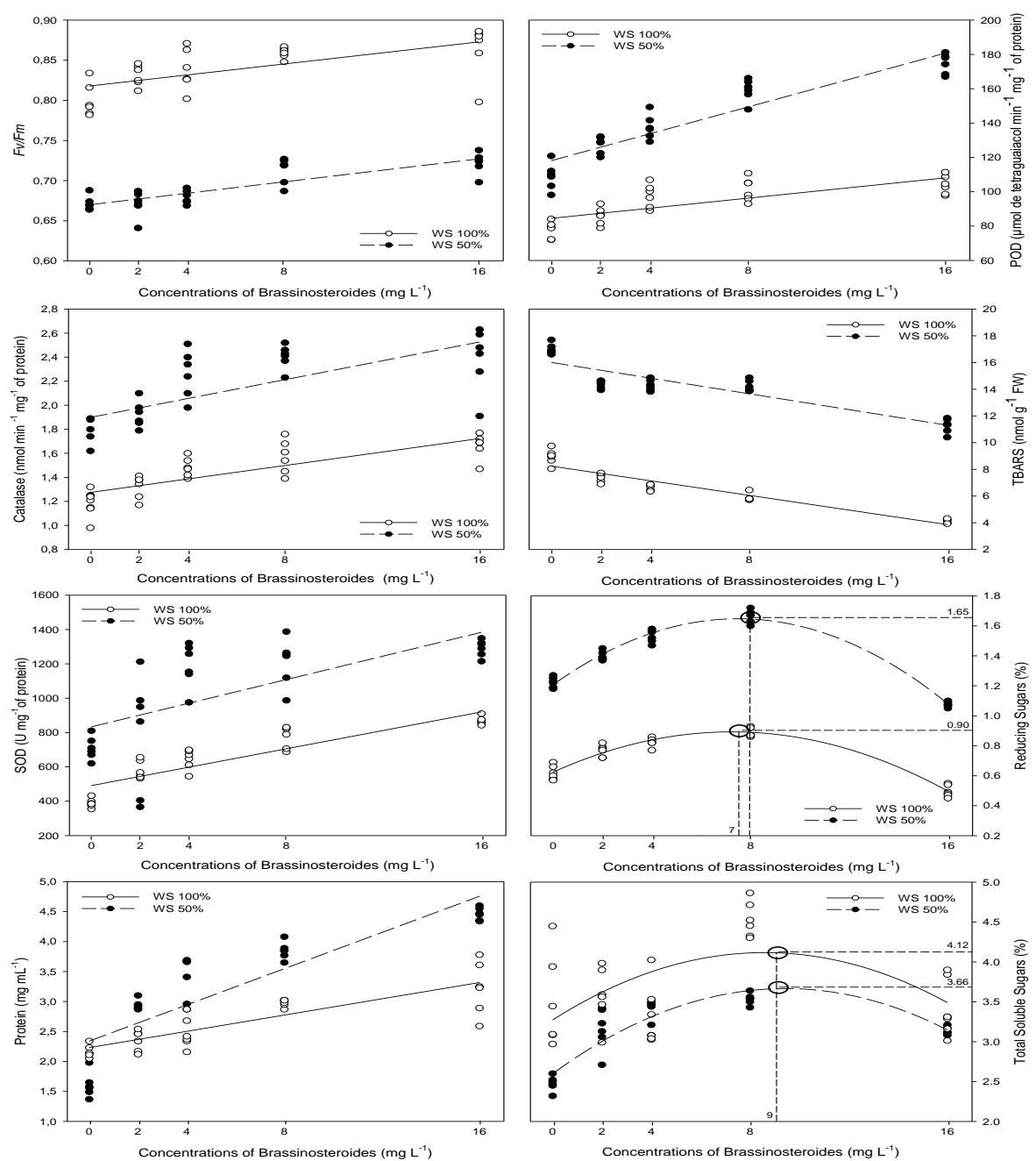

Fig 2. Regression equations for maximum quantum photosystem II efficiency $\left(F_{v} / F_{m}\right)$ (WS $50 \%: y=0.0036 x+0.670$. $R^{2}=0.91 * * ; W S$ $100 \%: y=0.0034 x+0.817 . R^{2}=0.90^{* *}$ ), POD (WS 50\%: $y=3.91 x+118.07 . R^{2}=0.93^{* *} ;$ WS $100 \%: y=1.47 x+84.49 . R^{2}=0.84 * *$ ), CAT (WS 50\%: $y=0.039 x+1.89 . R^{2}=0.87^{* *}$; WS 100\%: $y=0.028 x+1.27 . R^{2}=0.89 * *$ ), TBARS (WS 50\%: $y=-0.293 x+16.001 . R^{2}=0.92 * *$; WS 100\%: $\left.y=-0.273 x+8.24 . R^{2}=0.96 * *\right)$, SOD (WS 50\%: $y=34.41 x+833.21 . R^{2}=0.83 * * ;$ WS $100 \%: y=26.81 x+490.97 . R^{2}=0.89 * *$ ), reducing sugars (WS 50\%: $y=-0.0078 x^{2}+0.117 x+1.20 . R^{2}=0.98 * *$; WS $100 \%: y=-0.0051 x^{2}+0.074 x+0.623$. $R^{2}=0.97 * *$ ), protein $(W S$ $50 \%: y=0.15 x+2.34 . R^{2}=0.90 * *$; WS $\left.100 \%: y=0.067 x+2.23 . R^{2}=0.90 * *\right)$ and total soluble sugars (WS $50 \%: y=-0.0120 x^{2}+0.226 x$ +2.59. $\mathrm{R}^{2}=0.81^{* *}$; WS $100 \%: \mathrm{y}=-0.0114 \mathrm{x}^{2}+0.196 \mathrm{x}+3.27 . \mathrm{R}^{2}=0.81^{* *}$ ) of Jatropha curcas plants under different brassinosteroid concentrations and water supply (WS) levels. Regression equations significant at $* 5 \%$ and $* * 1 \%$ probability. Regression equation significant at $* 5 \%$ and ${ }^{* *} 1 \%$ probability. POD: Guaiacol peroxidase; CAT: catalase; SOD: superoxide dismutase; TBARS: thiobarbituric acid-reactive species. 
Table 3. Summary of the ANOVA and means test for catalase (CAT), superoxide dismutase (SOD), guaiacol peroxidase (POD), protein content (PR), total soluble sugars (AST), reducing sugars (AR) and non-reducing sugars (ANR) in Jatropha curcas plants submitted to water deficit (WD) and different brassinosteroid $(\mathrm{Br})$ concentrations.

\begin{tabular}{lllllllll}
\hline & \multicolumn{7}{c}{ Mean squares } \\
\cline { 2 - 10 } SV & DF & CAT & SOD & POD & PR & AST & AR & ANR \\
\hline Br & 4 & $0.8^{* *}$ & $5.8 \mathrm{E}+5^{* *}$ & $4.0 \mathrm{E}+3^{* *}$ & $6.7^{* *}$ & $1.8^{* *}$ & $0.5^{* *}$ & $0.9^{* *}$ \\
WD & 1 & $7.2^{* *}$ & $2.3 \mathrm{E}+6^{* *}$ & $3.5 \mathrm{E}+4^{* *}$ & $5.5^{* *}$ & $4.3^{* *}$ & $6.5^{* *}$ & $21.3^{* *}$ \\
Br×WD & 4 & $0.05^{\mathrm{ns}}$ & $4.7 \mathrm{E}+4^{*}$ & $753.4^{* *}$ & $1.4^{* *}$ & $0.6^{* *}$ & $0.01^{* *}$ & $0.7^{* *}$ \\
Residue & 50 & 0.03 & 16891.8 & 38.0 & 0.05 & 0.09 & 0.001 & 0.09 \\
CV, \% & & 8.8 & 15.4 & 5.3 & 7.8 & 8.9 & 3.5 & 12.8 \\
\hline Water supply (WS) & & Means & & & & & \\
\hline $100 \%$ & & $1.44 \mathrm{~b}$ & $651.89 \mathrm{~b}$ & $93.34 \mathrm{~b}$ & $2.64 \mathrm{~b}$ & $3.67 \mathrm{a}$ & $0.72 \mathrm{~b}$ & $2.95 \mathrm{a}$ \\
$50 \%$ & $2.12 \mathrm{a}$ & $1039.72 \mathrm{a}$ & $141.56 \mathrm{a}$ & $3.25 \mathrm{a}$ & $3.14 \mathrm{~b}$ & $1.38 \mathrm{a}$ & $1.76 \mathrm{~b}$ \\
\hline
\end{tabular}

CAT: $\mathrm{nmol} \mathrm{min} \mathrm{mg}^{-1}$ protein; SOD: $\mathrm{U} \mathrm{mg}^{-1}$ protein; POD: $\mu \mathrm{mol}$ tetraguaiacol $\mathrm{min}^{-1} \mathrm{mg}^{-1}$ protein; PR: $\mathrm{mg} \mathrm{mL}^{-1}$; AST: \%; AR: \%; ANR: \%.

*Significant at $5 \%$ probability; ** significant at $1 \%$ probability; $n$ s: nonsignificant by the $\mathrm{F}$ test. SuprimentoMeans followed by the same uppercase letter in the column do not differ at $5 \%$ probability by the Newman-Keuls test. Variation Source (SV), degrees of freedom (DF).
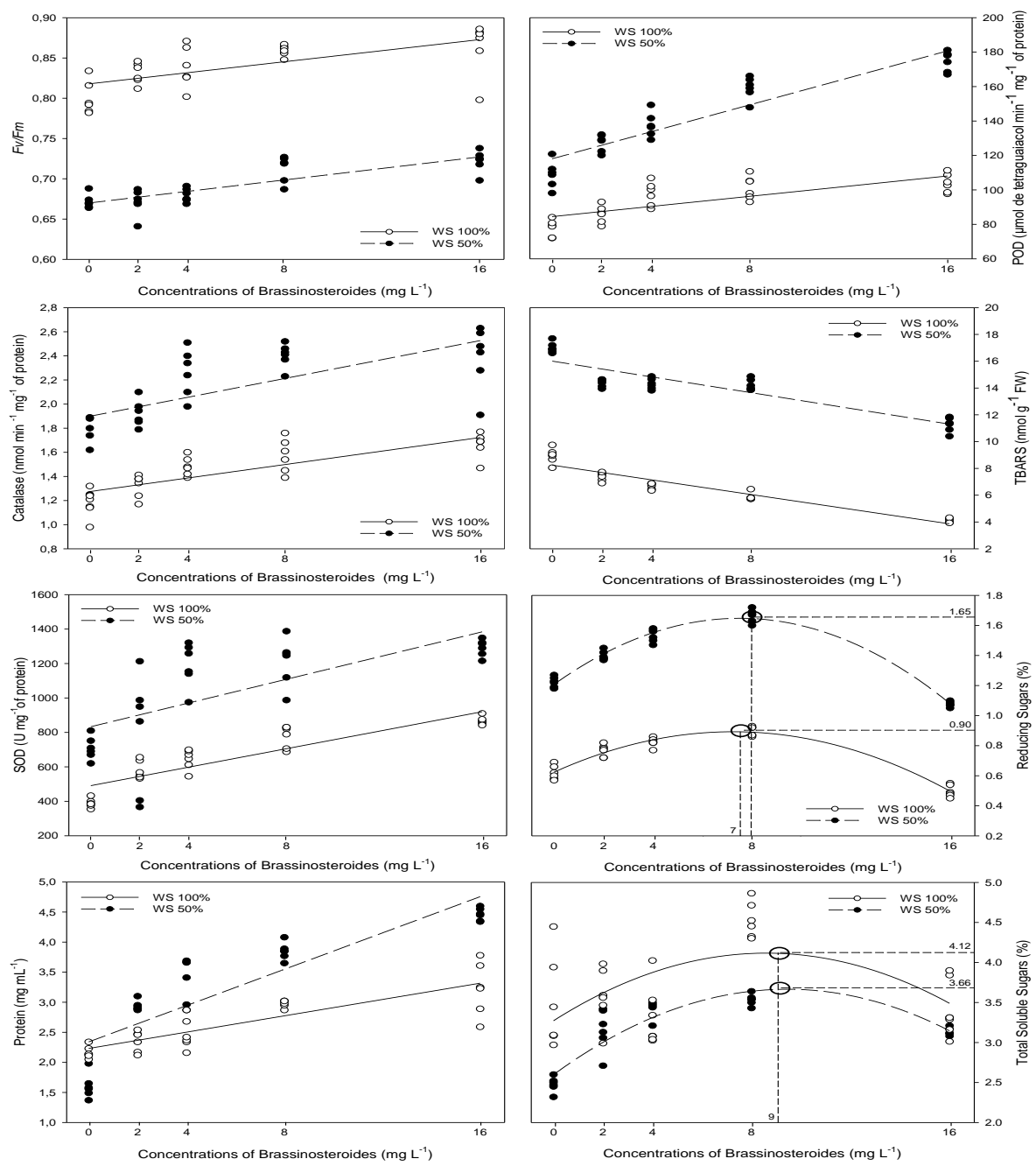

Fig 2. Regression equations for maximum quantum photosystem II efficiency $\left(F_{v} / F_{m}\right)$ (WS 50\%: $y=0.0036 x+0.670$. $R^{2}=0.91 * * ; W S$ $\left.100 \%: y=0.0034 x+0.817 . R^{2}=0.90^{* *}\right)$, POD (WS 50\%: $y=3.91 x+118.07 . R^{2}=0.93^{* *} ;$ WS $100 \%: y=1.47 x+84.49 . R^{2}=0.84 * *$ ), CAT (WS 50\%: $y=0.039 x+1.89 . R^{2}=0.87 * *$; WS 100\%: $y=0.028 x+1.27 . R^{2}=0.89 * *$ ), TBARS (WS 50\%: $y=-0.293 x+16.001 . R^{2}=0.92 * *$; WS $100 \%: y=-0.273 x+8.24 . R^{2}=0.96 * *$ ), SOD (WS 50\%: $y=34.41 x+833.21 . R^{2}=0.83 * * ;$ WS $100 \%: y=26.81 x+490.97 . R^{2}=0.89 * *$ ), reducing sugars (WS 50\%: $y=-0.0078 x^{2}+0.117 x+1.20 . R^{2}=0.98 * *$; WS $\left.100 \%: y=-0.0051 x^{2}+0.074 x+0.623 . R^{2}=0.97 * *\right)$, protein $($ WS $50 \%: y=0.15 x+2.34 . R^{2}=0.90 * *$; WS $\left.100 \%: y=0.067 x+2.23 . R^{2}=0.90^{* *}\right)$ and total soluble sugars (WS $50 \%: y=-0.0120 x^{2}+0.226 x$ +2.59. $R^{2}=0.81^{* *}$; WS $100 \%: y=-0.0114 x^{2}+0.196 x+3.27 . R^{2}=0.81^{* *}$ ) of Jatropha curcas plants under different brassinosteroid concentrations and water supply (WS) levels. Regression equations significant at $* 5 \%$ and $* * 1 \%$ probability. Regression equation significant at $* 5 \%$ and $* * 1 \%$ probability. POD: Guaiacol peroxidase; CAT: catalase; SOD: superoxide dismutase; TBARS: thiobarbituric acid-reactive species. 
photosystem II yield, stabilizing the D1 protein and other attributes of photosynthesis. Brassinosteroids may increase carboxylation efficiency and improve antioxidant enzyme systems in the leaves of plant species by reducing hydrogen peroxide $\left(\mathrm{H}_{2} \mathrm{O}_{2}\right)$ and malonaldehyde (Ogweno et al., 2008).

Increase in the leaf reducing sugar concentration and total soluble sugars may be associated to the energetic demand at the growth sites through higher glucose respiration and photosynthetic activity to maintain the plant vigor identified in Br-treated plants. It is also pointed out that the brassinosteroids activates the proton bomb with energetic demand for cell wall relaxation and plant tissue expansion, as reported by Taiz et al., (2017). Brassinosteroids also act on photosynthesis at various levels, improving carbohydrate synthesis (Siddiqui et al., 2018). Increase in leaf protein concentration may be related to increase in antioxidation enzymes (Ahammed et al., 2013) and/or synthesis of late embryogenesis abundant (LEA) proteins that act to maintain cell membrane integrity.

Under water deficit, J. curcas plants reduced transpiration by stomata control that concomitantly restricted $\mathrm{CO}_{2}$ inflow and limited plant growth. In addition, production increased of reactive substances that damage membranes and proteins, but the brassinosteroids activated photoprotection mechanisms, increased leaf transpiration and possibly $\mathrm{CO}_{2}$ inflow that sequentially resulted in higher photosynthesis and growth. The quadratic regression graphs with maximum points at the $8 \mathrm{mg}$ $\mathrm{L}^{-1}$ brassinosteroid concentration for plant growth and photoprotection system indicated that in J. curcas the $\mathrm{Br}$ dependent responses are maximized at the optimal hormone level in the plant tissue.

\section{Materials and Methods}

\section{General conditions and treatments}

The study was carried out in a greenhouse at the State University of Goiás, Ipameri Campus (17ㄴ3'19" S, 4809'35" W; 773 m) Ipameri, Goiás, Brazil, from September 2016 to January 2017, and a completely randomized design was used in a $5 \times 2$ factorial arrangement (plants submitted to five brassinosteroid concentrations: $0 ; 2 ; 4 ; 8 ; 16 \mathrm{mg} \mathrm{L}^{-1}$ and two levels of daily water supply: $50 \%$ and $100 \%$ daily evapotranspiration, six replications and a plot consisting of one useful plant. Jatropha curcas L. seeds were sown in $8 \mathrm{dm}^{3}$ plastic pots containing a mixture of six kilograms of soil (Oxisol), sand and cattle manure at 3:1:0.5, respectively.

Based on the chemical analysis of the mixture described below, it was decided not to lime and fertilize but at seven and 37 days after emergence, foliar fertilizers with micronutrients were applied using $30 \mathrm{ml}$ solution per plant and $1 / 3$ of the dose recommended by Dias et al. (2007): $\mathrm{pH}$ 5.4, $16 \mathrm{~g} \mathrm{dm}^{-3}$ organic matter, $68 \mathrm{mg} \mathrm{dm}^{-3} \mathrm{P}, 6.81 \mathrm{mmolc} \mathrm{dm}^{-3} \mathrm{~K}, 22 \mathrm{mmolc}$ $\mathrm{dm}^{-3} \mathrm{H}+\mathrm{Al}, 31 \mathrm{mmolc} \mathrm{dm}^{-3} \mathrm{Ca}, 15 \mathrm{mmolc} \mathrm{dm}^{-3} \mathrm{Mg}, 53 \mathrm{mmolc}$ $\mathrm{dm}^{-3}$, sum of bases, 75 mmolc $\mathrm{dm}^{-3}$ cation exchange capacity and $71 \%$ base saturation.

\section{Irrigation management}

The seedlings were irrigated daily with water volume corresponding to $100 \%$ of the daily evapotranspiration until 69 DAE. At 70 DAE water deficit treatment was imposed, subjecting half of the plants to water stress while the other half was irrigated daily, and at 100 DAE the analyzes were performed. Since the crop coefficient $(\mathrm{kc})$ for Jatropha curcas has yet to be determined for the Ipameri region (GO), a kc of 1.00 was applied in accordance with the FAO-56 estimate (Allen et al., 1998) for a group of crops in the initial growth stage. The water volume provided was estimated based on the reference evapotranspiration and crop coefficient. Crop evapotranspiration was determined using the equation: $(E T C=$ ETo $\mathrm{x} \mathrm{kc)}$ where: $\mathrm{ETc}=$ crop evapotranspiration; $\mathrm{kc}=$ crop coefficient; ETo = Reference evapotranspiration.

The daily ETo was calculated by the FAO Penman-Monteith method (Smith et al., 1991) using the daily data on minimum and maximum temperature, relative humidity, solar radiation and wind speed obtained from the INMET Weather Station located in the municipality of Ipameri, GO. Hormone treatment was made in two leaf applications so that every leaf received $10 \mathrm{~mL}$ solution at $30 \mathrm{DAE}$ and $20 \mathrm{~mL}$ at $60 \mathrm{DAE}$.

\section{Growth variables}

The plant height, stem diameter and root length were measured using a graded ruler and digital pachymeter, universal 125 series (Starett, Brasil) The leaf area was obtained following recommendations by Gonçalves et al., (2011). The destructive analyses were carried out separating the canopy from the root system, and both were placed in a chamber at $65{ }^{\circ} \mathrm{C}$ until constant DM was reached. The total biomass was calculated from the data obtained.

\section{Physiological variables}

The plant total daily transpiration was measured by the difference in pot weight. First, each pot was placed in a plastic bag and a rubber band tied around the plant stem, so that only the canopy (leaves and stem) remained outside the bag. The set of the plant, pot and plastic bag were weighed at 18:00 $\mathrm{h}$ (matter 01), and weighed again $24 \mathrm{~h}$ later (matter 02). The total transpiration was estimated from the difference between matter 01 and matter 02.

Electrolyte leakage was obtained by collecting ten $7 \mathrm{~mm}$ diameter leaf discs from completely opened leaves and immersing them in tubes containing $30 \mathrm{~mL}$ distilled water for $24 \mathrm{~h}$, at ambient temperature in the dark. The free conductivity of the sample was measured by a portable conductivity meter CD-880 (Eletro gehaka, Brasil) The tubes were placed in a chamber at $100{ }^{\circ} \mathrm{C}$ for $1 \mathrm{~h}$ to determine total conductivity $\left(\mu \mathrm{S} \mathrm{cm}^{-1}\right)$. The electrolyte release rate (\%) was calculated according to methodology by Vasquez-Tello et al., (1990) and Talukdar (2012).

Two $9 \mathrm{~mm}$ leaf discs were removed and squashed in a pestle and mortar with approximately $100 \mathrm{mg} \mathrm{CaCO}_{3}$ and $5 \mathrm{~mL}$ acetone $(80 \%)$ in an environment with green light. Chlorophyll and carotenoids were quantified by spectrophotometric readings at $470,646.8$ and $663.2 \mathrm{~nm}$, following recommendations by Lichtenthaler (1987).

The $F_{v} / F_{m}$ ratio (maximum quantum efficiency of photosystem II) was calculated using a JUNIOR-PAM portable fluorometer (Walz, Effeltrich, Germany) in the dark period at 04:00 $\mathrm{h}$ with $0.3 \mathrm{~s}$ saturating light emissivity $0.6 \mathrm{kHz}$, at $30 \mathrm{~d}$ after imposing the water deficit. The fluorescence data obtained were later computed using the WinControl-3 software (Walz, Germany). 


\section{Biochemical variables}

The biochemical assessments were made using samples from the third completely opened leaf from the apex. To quantify the antioxidant enzymes, approximately $1 \mathrm{~g}$ plant material was homogenized in $3 \mathrm{~mL}$ sodium phosphate buffer solution $(0.05$ $\mathrm{M}, \mathrm{pH} 7.8,1 \mathrm{mM}$ EDTA and polyvinylpyrrolidone $2 \% \mathrm{p} / \mathrm{v})$. The homogenate was centrifuged at $13.000 \times \mathrm{g}$ for $20 \mathrm{~min}$ at $4{ }^{\circ} \mathrm{C}$. The supernatant (crude extract) was used to determine the enzymatic activity and protein content (Pereira et al., 2018). Catalase (CAT) activity was determined according to Aebi (1984). The activity was monitored until the $\mathrm{H}_{2} \mathrm{O}_{2}$ disappeared, measuring the absorbency degrees at $240 \mathrm{~nm}$.

Guaiacol peroxidase (POD) activity was determined according to Zeraik et al., (2008) using guaiacol as substrate. The enzymatic activity was measured by oxidizing guaiacol in tetraguaiacol and analyzing absorbency at $470 \mathrm{~nm}$. Superoxide dismutase (SOD) activity was measured according to the spectrophotometric method described by Giannopolitis et al., (1977). The enzymatic activity was expressed by protein. Lipid peroxidation was determined by quantifying thiobarbituric acid-reactive species (TBARS), as described by Cakmak et al., (1991).

Total soluble protein content was determined from $25 \mu \mathrm{L}$ root extract mixed in a reaction solution (Coomassie Blue G 250 prepared with orthophosphoric acid ethanol). The reading was made in a Nova 1600 UV spectrophotometer (Nova instruments, Brasil) at $595 \mathrm{~nm}$ (Bradford, 1976). To analyze sugars and starch, approximately $200 \mathrm{mg}$ leaf tissue were immersed in $80 \%$ ethanol, heated to $65{ }^{\circ} \mathrm{C}$ for $30 \mathrm{~min}$, centrifuged and the supernatant collected in a new tube. The ethanolic extract was used to quantify total soluble sugars by the phenol sulfuric method with reading at $490 \mathrm{~nm}$ wavelength, using a standard sucrose curve and the reducing sugars were determined according to the dinitrosalicylic acid method following recommendations by Miller (1959), at 540 $\mathrm{nm}$ absorbance using a standard glucose curve. The nonreducing sugars were estimated by the differences between total soluble and reducing sugar contents. Starch was determined according to McCready et al., (1950) at $490 \mathrm{~nm}$ wavelength and standard sucrose curve at an interval of 0 to $50 \mu \mathrm{g}$.

\section{Statistical analysis}

Variables were submitted to ANOVA and differences between treatments were analyzed by the Newman-Keuls test at $5 \%$ level of probability. In addition, regression analysis was made with the respective coefficients of determination $\left(R^{2}\right)$ and graphics, using the $R 3.4$ ( $R$ Foundation for Statistical Computing, Vienna, Austria).

\section{Conclusions}

Brassinosteroids played an important role in mitigating the deleterious effects of water deficit on J. curcas plants by acting as an elicitor in activating photoprotection mechanisms, increasing vegetative growth and maintaining membrane integrity.
The e antioxidant and growth machinery activation reached maximum points at the $8 \mathrm{mg} \mathrm{L}^{-1}$ brassinosteroid concentration and supplied at higher concentrations.

\section{Acknowledgements}

The authors would like to thank the Brazilian Council for Scientific and Technological Development (CNPq) and Universidade Estadual de Goiás for the research fellowships, the Instituto Federal Goiano (IFG) - Câmpus Urutaí for making the laboratory available for biochemical analysis.

\section{References}

Aebi H (1984) Catalase in vitro. Methods Enzymol. 105:121126.

Ahammed GJ, Ruan YP, Zhou J, Xia XJ, Shi K, Zhou YH (2013) Brassinosteroid alleviates polychlorinated biphenyls induced oxidative stress by enhancing antioxidant enzymes activity in tomato. Chemosphere. 90(11):2645-2653.

Allen RG, Pereira LS, Raes D, Smith M (1998) Crop evapotranspiration: guidelines for computing crop water requirements. FAO Irrigation and Drainage Document $N^{0} .56$. FAO, Rome, Italy.

Bartwal A, Mall R, Lohani P, Guru SK, Arora S (2013) Role of secondary metabolites and brassinosteroids in plant defense against environmental stresses. J Plant Growth Regul. 31(1):216-232.

Bradford MM (1976) A rapid and sensitive method for the qualification of microgram quantities of protein utility the principle of protein dye binding. Anal Biochem. 7:248-254.

Cakmak I, Horst WJ (1991) Effect of aluminum on lipid peroxidation, superoxide dismutase, catalase, and peroxidase activities on root tips of soybean (Glycine max). Physiol Plant. 83:463-468.

Chaves MCC, Gomes CFS (2014) Avaliação de biocombustíveis utilizando o apoio multicritério à decisão. Production. 24(3):495-507.

Díaz-López L, Gimeno V, Isimón I, Martínez V, RodríguezOrtega WM, García-Sánchez F (2012) Jatropha curcas seedlings show a water conservation strategy under drought conditions based on decreasing leaf growth and stomatal conductance. Agric Water Manag. 105 (9):48-56.

Divi UK, Rahman T, Krishna P (2016) Gene expression and functional analyses in brassinosteroid-mediated stress tolerance. Plant Biotechnol J. 14(1):419-432.

Dos Anjos RAR, Santos LCS, Oliveira DB, Amaro CL, Rios JM, Rocha GT (2017) Initial growth of Jatropha curcas plants subjected to drought stress and silicon (Si) fertilization. AJCS. 11(4)479-484.

Durães FOM, Laviola BG, Alves AA (2011) Potential and challenges in making physic nut (Jatropha curcas L.) a viable biofuel crop: the Brazilian perspective. CAB Reviews. 6(43):18.

Fini A, Bellasioa C, Pollastri S, Tattini M, Ferrini F (2013) Water relations, growth, and leaf gas exchange as affected by water stress in Jatropha curcas. J Arid Environ. 89:21-29.

Giannopolitis CN, Ries SK (1977) Purification and quantitative relationship with water soluble protein in seedlings. J Plant Physiol. 48:315-318. 
Gonçalves WG, Costa AC, Lima DP, Silva AA, Megguer CA (2011) Membrane permeability and relative water content in physic nuts plants submitted to fast water deficit. Global Science and Technology. 4:131-139.

Hilgenberg T, Ayub RA (2014) Avaliação de Brassinosteróides na quebra de dormência e no crescimento de ramos de Macieira (Malus domestica). Ambiência. 10(2):625-630.

Khamsuk O, Sonjaroon W, Suwanwong S, Jutamanee $\mathrm{K}$, Suksamrarn A (2018) Effects of 24-epibrassinolide and the synthetic brassinosteroid mimic on chili pepper under drought. Acta Physiol Plant. 40:106.

Lichtenthaler HK (1987) Chlorophylls and carotenoids: Pigments of photosynthetic biomembranes. Methods Enzymol. 148:350-382.

Matos FS, Ciappina AL, Rocha EC, Almeida LM (2018) Factors that influence in Jatropha curcas L. latex production. Bragantia. 77(1):74-82.

Matos, FS, Torres, HDJ, Rosa, VR, Santos PGF, Borges LFO, Neves TG (2014) Estratégia morfofisiológica de tolerância ao déficit hídrico de mudas de pinhão manso. Magistra. 26(1)19-27.

McCready RM, Guggolz J, Silviera V, Owens HS (1950) Determination of starch and amylose in vegetables. Anal Chem. 22:1156-1158.

Miller GL (1959) Use of dinitrosalicylic acid reagent for determination of reducing sugar. Anal Chem. 31(3):426-428.

Moura AR, Nogueira RJMC, Da Silva JAA, De Lima TV (2016) Relações hídricas e solutos orgânicos em plantas jovens de Jatropha curcas L. sob diferentes regimes hídricos. Ciência Florestal. 26(2):345-354.

Ogweno JO, Song XS, Shi K, Hu WH, Mao WH, Zhou YH (2008) Brassinosteroids alleviate heat-induced inhibition of photosynthesis by increasing carboxylation efficiency and enhancing antioxidant systems in Lycopersicon esculentum. J Plant Growth Regul. 27(1):49-57.
Osakabe Y, Osakabe K, Shinozaki K, Tran LSP (2014) Response of plants to water stress. Plant Sci. 5:1-8.

Pereira AS, Dorneles AOS, Bernardy K, Sasso VM, Bernardy D, Possebom G (2018) Selenium and silicon reduce cadmium uptake and mitigate cadmium toxicity in Pfaffia glomerata (Spreng.) Pedersen plants by activation antioxidant enzyme system. Environ Sci Pollut R. 25:18548-18558.

Siddiqui H, Hayat S, Bajguz A (2018) Regulation of photosynthesis by brassinosteroids in plants. Acta Physiol Plant. 40(1):59.

Smith M (1991) Report on the expert consultation on revision of FAO methodologies for crop water requirements. FAO Irrigation and Drainage Document. FAO, Rome, Italy, 1-45.

Taiz L, Zeiger E (2017) Fisiologia vegetal. 858 p. 6 ed. ArtMed, Porto Alegre, Brazil.

Dias LAS, Leme LP, Laviola BG, Pallini A, Pereira OL, Carvalho M (2007) Cultivo de pinhão-manso (Jatropha curcas L.) para produção de óleo combustível. 40 p. Editora UFV, Viçosa, Brasil.

Talukdar D (2012) Arsenic-induced oxidative stress in the common bean legume, Phaseolus vulgaris $L$. seedlings and its amelioration by exogenous nitric oxide. Physiol Mol Biol Plants. 19(1): 69-79.

Unterholzner SJ, Rozhon W, Papacek M, Ciomas J, Lange T, Kugler KG (2015) Brassinosteroids are master regulators of gibberellin biosynthesis in Arabidopsis. Plant Cell. 27(8):2261-2272.

Vasquez-Tello AY, Zuily-Fodil AT, Pham Thi J, Vieira S (1990) Electrolyte and Pi leakages and soluble sugar content as physiological tests for screening resistance to water stress in Phaseolus and Vigna species. J Exp Bot. 41:827-832.

Zeraik AE, Souza FS, Fatibello-Filho O (2008) Development of a spot test for peroxidase activity monitoring during a purification procedure. Química Nova. 31:731-734. 